Cambridge Archaeological Journal

http://journals.cambridge.org/CAJ

Additional services for Cambridge Archaeological Journal:

Email alerts: $\underline{\text { Click here }}$

Subscriptions: Click here

Commercial reprints: Click here

Terms of use : $\underline{\text { Click here }}$

\title{
Objects with Attitude: Biographical Facts and Fallacies in the Study of Late Bronze Age and Early Iron Age Warrior Graves
}

James Whitley

Cambridge Archaeological Journal / Volume 12 / Issue 02 / October 2002, pp 217 - 232

DOI: 10.1017/S0959774302000112, Published online: 09 December 2002

Link to this article: http://journals.cambridge.org/abstract_S0959774302000112

How to cite this article:

James Whitley (2002). Objects with Attitude: Biographical Facts and Fallacies in the Study of Late Bronze Age and Early Iron Age Warrior Graves. Cambridge Archaeological Journal, 12, pp 217-232 doi:10.1017/S0959774302000112

Request Permissions : $\underline{\text { Click here }}$ 


\title{
Objects with Attitude: Biographical Facts and Fallacies in the Study of Late Bronze Age and Early Iron Age Warrior Graves
}

\author{
James Whitley
}

\begin{abstract}
Aegean prehistory still has to deal with the legacy of 'Homeric archaeology'. One of these legacies is the 'warrior grave', or practice of burying individuals (men?) with weapons which we find both in the Late Bronze Age and the Early Iron Age in the Aegean. This article suggests that the differences between the 'weapon burial rituals' in these two periods can tell us much about the kind of social and cultural changes that took place across the Bronze Age/Iron Age 'divide' of c. 1100 BC. In neither period, however, can items deposited in 'warrior graves' be seen as straightforward biographical facts that tell us what the individual did and suffered in life. Rather, the pattern of grave goods should be seen as a metaphor for a particular kind of identity and ideal. It is only in the Early Iron Age that this identity begins to correspond to the concept of the 'hero' as described in the Iliad. One means towards our better understanding of this new identity is to follow up work in anthropology on the biography of objects. It is argued that the 'life cycle' of 'entangled objects', a cycle which ends in deposition in a grave, provides us with indispensable clues about the nature of new social identities in Early Iron Age Greece.
\end{abstract}

The study of Aegean prehistory, especially the Late Bronze and Iron Ages, still bears the impress of the beliefs and theories of the pioneers of the discipline. This is not simply because Schliemann's, Dörpfeld's or Evans' ideas maintain a certain hold on current practitioners in the field. The study of Aegean prehistory began as Homeric archaeology — that is, as a means by which the historical truth of Homer could be substantiated by material evidence. In recent years attempts have been made to free Aegean prehistory from this incubus of literary preconception. Greek prehistory is to be reconstructed from the ground up. The old Neoclassical edifice of Homeric archaeology is to be demolished, and the Neolithic is to provide the foundation for a new structure built, like the works of a Richard Rogers or a Norman Foster, from the steel of theory and the transparent glass of new discovery. Homeric archaeology is dead. Long live Aegean prehistory!

I find myself in disagreement with this recent tendency. To ignore Homer is to ignore the driving force behind the creation of Aegean archaeology. It is to render such figures as Schliemann, Tsountas, Blegen and Evans unintelligible to modern practitioners, a process which (perversely) reinforces their status as the 'founding fathers' of the subject. Historiography is moreover an essential part of a critical and theoretically-informed archaeological practice. In Aegean archaeology, an aversion to the literary preoccupations of earlier scholars has also contributed to a sidelining of the Iron Age. Unlike their Bronze Age colleagues, Iron Age specialists cannot afford to ignore Homer. The reason for this is simple. Since the first publication of Finley's 'World of Odysseus' in 1954 (Finley 1979) the debate about the historicity of Homer has gradually seemed less and less relevant to our understanding of the Bronze Age (Bennet 1997). It is now widely believed that, if Homer refers to any historical reality at all, it is an Iron Age or eighth-century reality, not a Bronze Age 


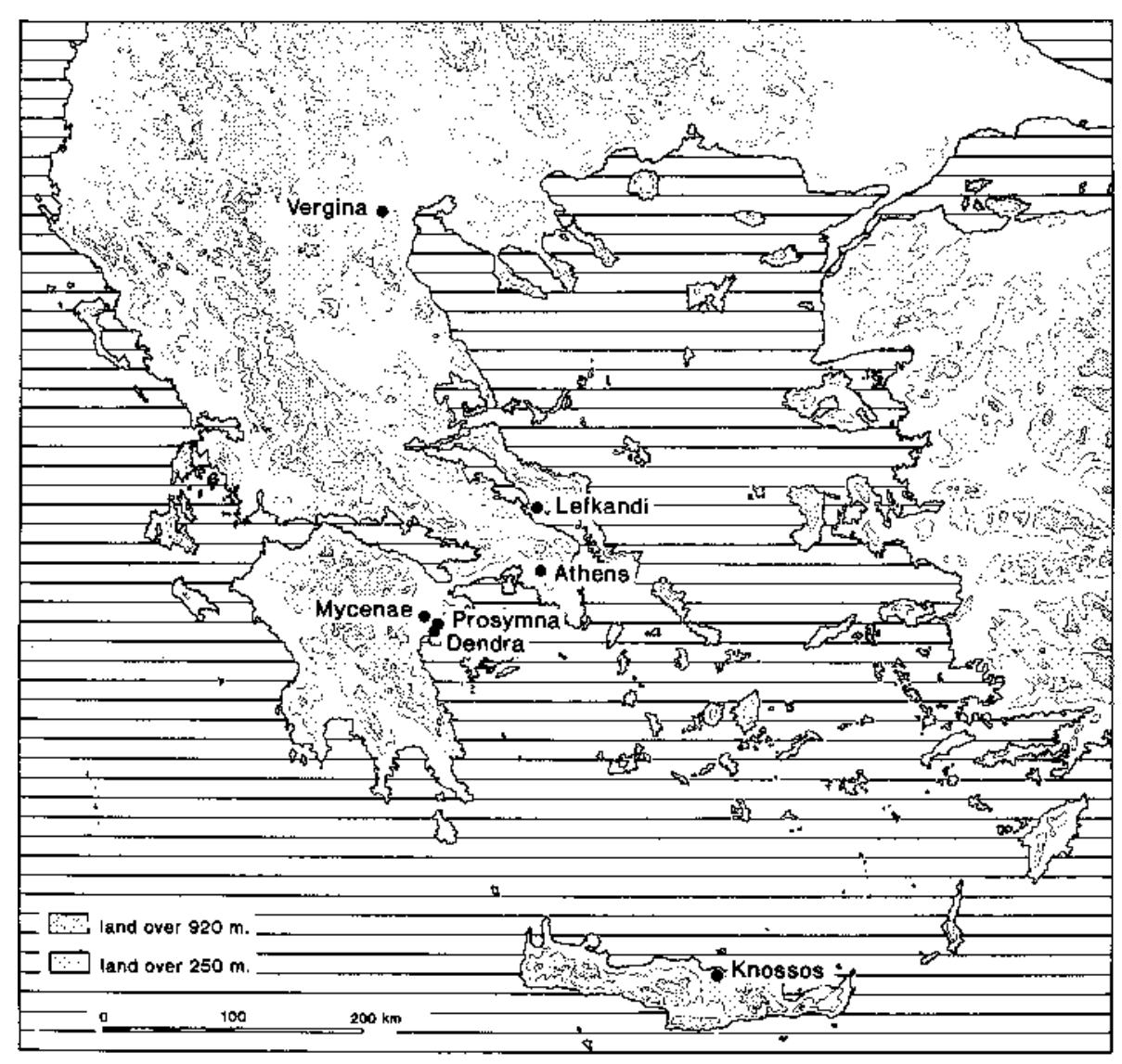

Figure 1. Map of Greece/Eastern Mediterranean, showing sites mentioned in text. (Drawing by H. Mason.)

one. Increasingly, the debate about 'Homeric society' is a debate about the relevance of Homer to our understanding of Early Iron Age and early Archaic society (I. Morris 1997; 2000, 77-106). It is as if Iron Age specialists have been left holding the whole embarassing legacy of 'Homeric archaeology', leaving Bronze Age scholars to become more and more comfortable with the idea that, once the palaces were destroyed, prehistory came to a...

'1100 $\mathrm{BC}^{\prime}$ has now become the point at which the Aegean prehistorian ends his narrative, and the Classical archaeologist begins his. But a disciplinary divide at 1200 or $1100 \mathrm{BC}$ is no more rational than one at 800 or 776 вс. Indeed one problem with a divide along these lines is not merely that it makes the study of the period of the transition much more difficult. It also makes it harder to appreciate that both Bronze and Iron age specialists share a common problem: how to deal with the legacy of 'Homeric archaeology', and the concepts that 'Homeric archaeology' helped to create.

The Homeric poems (particularly the Iliad) are pre-eminently poems about heroes - that is, in large part, about warriors. ${ }^{1}$ One of the most tenacious legacies of Homeric archaeology is the so-called 'warrior grave'. Both Schliemann's excavations of Grave Circle A at Mycenae (Schliemann 1880), and Evans' at the Zapher Papoura cemetery near Knossos (Evans 1905) revealed numerous burials with weapons - burials which were, without further examination, presumed to be male. A more fitting confirmation that the Bronze Age was the age of Homer's heroes could not be imagined. Though some doubts about the equation between weapons and warriors were raised as early as the 1920 s (e.g. Casson 1925, 21), 'warrior graves' and a 'warrior aristocracy' have none the less become an integral part of the conceptual furniture of Aegean archaeology (e.g. Hood 1956, 83n.2; DegerJalkotzy 1999; Papadopoulos 1999; Kilian-Dirlmeier 1990, 158).

Such graves are, to be sure, a feature of both the Late Bronze Age and Early Iron Age Aegean world. The practice of burying men with weapons might at first sight seem to indicate a considerable degree of continuity between these two periods. Indeed the continuation of this 'weapon burial ritual' (to borrow a term used in the study of Early Anglo-Saxon England) may, to some, indicate that the cultures of the Late Bronze and Early Iron Ages did not, in fact, fundamentally differ from one another. To be sure there were discontinuities in burial practices (so this argument might run), but the introduction of cremation, and the gradual decline in multiple as opposed to single burial might not be seen as terribly important. To an eye unprejudiced by the connotations of palatial collapse, it is the similarity between the burial practices to be found in the Zapher Papoura cemetery in Knossos and those later to be found in Subminoan and Early Protogeometric interments in the North Cemetery that should be stressed. There is something to be said for this argument. The Bronze 
Age and Iron Age worlds were certainly no strangers to one another, and the demise of the 'weapon burial ritual' in much of the central Aegean area in the eighth century BC is certainly an important historical watershed (I. Morris 1998, 19). It is my contention, however, that there are significant differences between Late Bronze Age and Early Iron Age weapon burial rituals. Indeed, the new configuration of practice we see in the Early Iron Age gives us a tantalizing glimpse of what seems to be a new conception of the masculine self and of the narratives that reinforce it. These narratives depend in turn on biographies, but biographies not of persons but of things.

\section{The biographical fallacy}

A common and 'common-sense' reading of grave goods, and so of graves with weapons, would see them as straightforward biographical facts. A warrior grave is a grave of a warrior, just as a rose is a rose is a rose. This 'common sense' reading of grave assemblages has in part been reinforced by a common misinterpretation of the theoretical framework first formulated by Binford (1972) and Saxe (1970). Role theory in general, and the concepts of vertical and horizontal status in particular, can easily be seen to confirm the 'common sense' idea that the grave goods interred with a man or woman in death provide us with a good indication of what a man or woman did or suffered in life. Here, however, I want to turn common sense on its head; it is the cultural biographies of things (insofar as they can be inferred) that provide us with essential clues as to the true meaning of warrior graves. So-called warrior graves are not necessarily graves of warriors. As in all aspects of material culture, the connotations of grave goods are as likely to be metaphorical as metonymic (Tilley 1999, 36-76; J. Thomas 1991). But the belief in common sense (that is, the idea that our sense is what we have in common with the peoples of the ancient world) is tenaciously held in traditional Classical Archaeology, and nowhere more so than in the case of the most celebrated of all Classical Greek warrior graves: the 'tomb of Philip II'.

The 'tomb of Philip' at Vergina is one of the most spectacular finds of the past few decades. The unplundered tomb contained the cremated remains of a man, a casket, a diadem, and a quantity of gold and silver vessels suitable for a symposion. It also contained arms and armour, including several iron spearheads, an iron sword, a helmet, an iron and gold cuirass and a chryselephantine shield (Andronikos 1994, 119-75). It clearly falls into the class of 'warrior graves', as the term is usually understood, and indeed it is this fact that has been used to support its identification as the tomb of Philip II, rather than Alexander's ineffectual successor, Philip Arrhidaios. As Andronikos puts it:

The wealth and the quality of the armour found in the tomb is totally incompatible with the non-martial Philip Arrhidaios. The magnificent iron cuirass and the gold and ivory shield alone should be enough to convince us that the deceased must have been a much more important king than he (Philip Arrhidaios) was. (Andronikos 1994, 228)

In other words, an elaborately furnished 'warrior grave' must be the grave of a great warrior. Well, not necessarily. For one thing, the osteological evidence (Xirotiris \& Langenscheidt 1981, 144-54) is compatible with either interpretation, since both Philip II and Philip Arrhidaios were in middle age when they died. Moreover, there is evidence from other Macedonian tombs to show that burial with weapons was a common feature of aristocratic burials in general and 'Royal tombs' in particular. Tomb Beta at Derveni is a case in point. This too is a cremation (in a bronze krater). Like the tomb of Philip II, it is accompanied by numerous symposion vessels, by armour and by weapons. But the cremation itself is of both a man and a woman (Themelis \& Touratsoglou 1997, 60-92; Musgrave 1990, 310-21). However we interpret this assemblage, we cannot see these objects as straightforward biographical facts that relate equally to both interments. The grave goods then must be seen in some sense as metaphors, and interpreted within a wider, northern Greek cultural framework where burial with weapons was very much the norm (I. Morris 1998, 43-5; Votokopoulou 1986). Nor is the 'tomb of Philip II' the only Royal 'warrior grave' at Vergina. The same pattern - cremation within metal vessel, arms, armour and symposion vessels - are to be seen in the so-called 'Prince's tomb' (Andronikos 1994, 198-217; Xirotiris \& Langenscheidt 1981, 157-60). The conclusion is inescapable. The historical, biographical fact that Arrhidaios was no warrior and not much of a king has no bearing on the way in which others (in this case Cassander) might have chosen to bury him. A Macedonian king was, by definition, a warrior (even if he wasn't) and had to be buried accordingly.

Now all this does not constitute proof that 'the tomb of Philip' was not the tomb of Philip II. Nor, by itself, would it convince a sceptic that warrior graves might not be exactly what they seem. If there is 'proof' it is indirect, and comes from another area where 'warrior graves' were common: pagan Early 
Anglo-Saxon England. As is too rarely the case in Greece, a large number of the human bones from these English graves have been subjected to detailed osteological study. This enabled Heinrich Härke to compare the grave goods with the osteology. He found that many of the graves accompanied by the largest and fanciest iron weapons were of adolescents (12- or 14-year-olds) too young to be able to wield such weapons effectively. Conversely, a study of the pathology of many of the skeletons buried without weapons revealed a surprisingly large number of injuries consistent with war wounds (Härke 1990; 1992). In brief, many burials with weapons were not those of warriors, and many 'real' warriors were not buried with weapons. Härke argued from this that we should stop looking at grave assemblages in literal-minded fashion, as if objects were straightforward indications of what individuals did in life. Instead we should see this 'weapon burial ritual' in more symbolic terms, as a metaphor for a certain kind of masculine ideal. Burial with weapons was a means by which a nexus of associations between masculinity, prowess in battle and political authority could be re-affirmed, an honour bestowed as much on those who had inherited the status of warrior as on those who had earned it.

But if this interpretation of grave goods as straightforward biographical facts is likely to be fallacious, that is not to exclude the notion of biography altogether. For, as anthropologists have argued, things too can acquire a kind of biography, and it is through a close study of such 'biographical objects' that we can gain a better understanding of the different connotations of Late Bronze Age warrior graves on the one hand and Early Iron Age ones on the other.

\section{Biographical objects: genealogy, gender and exchange}

In recent years, anthropologists have begun to rediscover the important role that objects play in social life. Indeed, in many cultures it is through objects rather than straightforward 'autobiographies' that men and women find ways of telling the story of their lives. Such objects need not be striking or ostentatious. In one instance, it is a plain 'betel bag' that serves as the point of reference for one man's story of his life and his relations with his ancestors, wives and sons (Hoskins 1998, 25-58). In parts of Melanesia or Polynesia, however, objects often assume a more public role, more obviously connected to systems of exchange, descent and legitimation. In these circumstances, a cultural biography of an object is produced by the stories told about the past history of who made it and who passed it on to whom. In some extreme cases, a history of production and exchange can invest an object with a kind of cultural 'personality' (Appadurai 1986a; Kopytoff 1986). The value of certain Maori objects classified as taonga, for example, does not derive so much from the quality of the craftsmanship or the rarity of the materials used as on its identity, an identity which derives not simply from its current owner but from 'the cumulative social and cosmological identities of past owners' (Weiner 1992, 63). Nor need such objects be 'traditional'. In special circumstances, an exotic object may come to be invested with special status, and become 'entangled' in a new social environment. One such circumstance was the decisive intervention of a certain Captain Potter in the intertribal wars of the Marquesas in the beginning of the nineteenth century (N. Thomas 1991, 98-100). It was only after this that muskets acquired a special status. As Nicholas Thomas puts it:

... articles of trade dispensed as commodities were reconstituted as inalienable gifts from foreigners by Marquesans. This was the sense in which an old gun was not merely useful (as a weapon) but singular: the artifact embodies the narrative of Potter's alliance with the Taiohae people, and its possession stood for the continuing association between them and American power (N. Thomas 1991, 91-100).

Thomas is here arguing against the idea that 'primitive economies' are almost exclusively concerned with gifts (which are personal, and have associations), whereas modern economies deal mainly in impersonal commodities, whose value is not so much sentimental but utilitarian or monetary. Thomas shows how commodities and gift exchange, sentimental and market value co-exist in both 'primitive' and modern economies. Objects which begin as commodities (such as Potter's gun) can become entangled in a new set of social relationships. In doing so they acquire their own 'biographies'. One of the ways objects move from one sphere to the other in our own society is through their acquisition by museums. Museum accession labels often list the 'biographical details' of an object: who originally made it, who acquired it, who donated it to the museum (e.g. Gosden \& Marshall 1999, 170-72). Such objects are not simply adjuncts to the biographies of people. 'Material things are not external support or measures of an internal life, but rather people and things have mutual biographies which unfold in culturally 
specific ways' (Gosden \& Marshall 1999, 173).

These ideas have been taken up enthusiastically by European prehistorians (e.g. Tilley 1996, 247-324; Edmonds 1999, 42). But Neolithic specialists have been unable to say anything very specific about how the meaning of a particular object might have changed through the course of its 'life' - objects are just said to have had 'rich biographies'. Rarely has the distinction between 'objects which can accumulate biographies to themselves and objects which contribute to the biography of a ceremony or body of knowledge' (Gosden \& Marshall $1999,176)$ been observed. Here those working in protohistoric periods are at an advantage. Legends, tales and epic poetry may not convey very much in the way of historical fact, but they often tell us a great deal about the social lives of things. In his study of Anglo-Saxon swords, for example, Härke was able to combine literary and archaeological evidence to say something very specific about the role of weapons - particularly ancient weapons in AngloSaxon society (Härke 2000, 393-6). ${ }^{2}$ The tight relative chronologies of protohistoric periods also allow archaeologists to be more precise as to the length of time an object may have been in use. Langdon (2001) has noted that many pots deposited in Thebes and Argos in the eighth century were c. 25-50 years old at the time of their deposition, and she has shown that this 'biographical' fact has a direct bearing on our interpretations of the burials in which they were found, the other artefacts associated therein, and the imagery on the pots themselves.

Though pots do not form a part of the world of the Homeric poems, objects with biographies certainly do. Furthermore, the way they are described tells us something about the status of their owners, givers or recipients. In the brief account of Agamemnon's sceptre (Iliad II.100-108) we are told that this object was first made by Hephaistos for Zeus, who in turn gave it to Hermes, who gave it to Pelops, who gave it to Atreus, who gave it to Thyestes who gave it in turn to Agamemnon. The genealogy of the object mirrors in part the genealogy of Agamemnon, and speaks eloquently of his status as High King. Equally, the famous boars' tusk helmet which Meriones gives to Odysseus (Iliad X.260-70) is clearly an antique whose value derives from its entanglement within an extensive aristocratic exchange network. The objects most frequently mentioned in Homer, however, are silver kraters, which, as Sarah Morris (1997) has pointed out, all seem to have a Near Eastern pedigree. The one that Menelaus gives to Telemachus (Odyssey IV.611-55) was originally given to Menelaus by Phaidimos, king of Sidon. The silver krater that Achilles picks as a prize in the funeral games of Patroclus (Iliad XXIII.740-49) has a more extensive genealogy. It was made by Sidonians, carried over the sea by Phoenicians, given in turn to Thoas, and then given in turn to Patroclus by Euenos, son of Priam, as a ransom for Lykaon. What must be stressed here is not simply that this krater 'accumulates a biography to itself', but also that its value derives from its history and from its entanglement with the 'life stories' of Thoas, Euenos, Lykaon, Patroclus and Achilles. Object biographies and heroic narratives intertwine.

Such objects tend to be of relatively precious metal (silver, and occasionally bronze) or other rare materials (boar's tusk). Objects in humble clay do not seem to circulate in the elevated social circles of the Iliad and the Odyssey. These objects relate quite specifically to heroic narratives - their biographies intertwine with the 'biographies' of the heroes within the overarching structure of the poem. Might then the narratives of the 'real' warriors and 'real' objects we can observe in the archaeological record have intertwined in a similar fashion? It would at least be interesting to see if any objects which were likely candidates for such a status were actually found in the same graves as those with weapons. Let us start with the Late Bronze Age.

\section{Late Bronze Age 'warrior graves'}

The most celebrated 'warrior graves' in Bronze Age Greece are, of course, those found in Shaft Grave Circle A at Mycenae. Graves IV, V and VI in Circle A are full of weapons apparently associated with males, together with exotica and other rich grave goods. ${ }^{3}$ Examples of this 'weapon burial ritual' in other parts of the Argolid during the latter part of the Late Bronze Age are, however, rarer than one might think. Only two chamber tombs at Mycenae and four at Prosymna have interments with bronze daggers or swords. ${ }^{4}$ The graves at Dendra near Midea form a spectacular exception to this rule. The cuirass tomb (Åström 1977) is a rich grave, apparently of an adult man, with a boars' tusk helmet, bronze greaves, a bronze cuirass and two 'ceremonial' swords of bronze, ivory and gold. The extended inhumation in the 'King's tholos' is even richer, accompanied as it is by numerous bronze, gold and silver vessels and at least five bronze swords (Persson 1931). It would clearly be absurd to see these grave goods as simply 'biographical' about either individual. Under what circumstances could the individual in the King's tholos, 


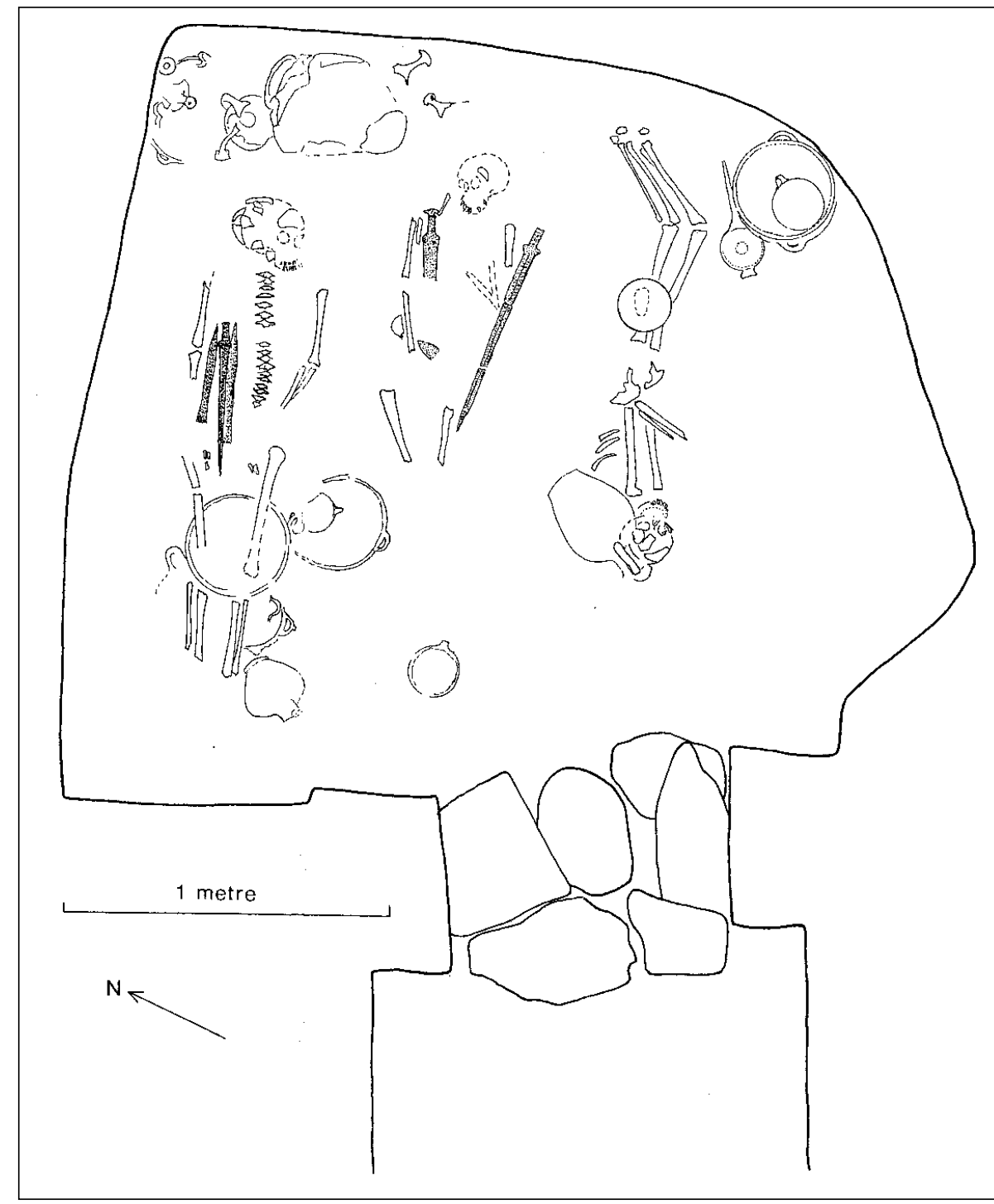

Figure 2. Plan of Sellopoulo grave 4 at Knossos, showing swords, daggers and spearheads in relation to the inhumation burials I and II. (Redrawn by H. Mason, after Popham \& Catling 1974, 200 fig. 3, 226 fig. 15.)

described as being a man 'of small stature and narrow across the shoulder and hips' (Persson 1931, 16) have wielded all five of his swords? The symbolism is redundant, and this is clearly a case where the status of a 'warrior' is being ascribed by others rather than having been achieved by the man himself.

Surprisingly, perhaps the greatest concentration of 'warrior graves' in the Late Bronze Age Aegean are not to be found in the 'Mycenaean' Argolid but in 'Minoan' Knossos. Of course, the accepted interpretation of these graves - all dating to LMII or LMIIIA c. 1450-1350 BC) - is that these were the graves of warriors who formed the entourage of the new Mycenaean king of Knossos, a military arrangement which may have been referred to in the Linear B tablets (Driessen \& MacDonald 1984). This practice is certainly an innovation in LMII. Burials with weapons, 18 in all, are to be found in an arc extending from the Acropolis hill (1 grave), through Ayios Ioannis (2 graves), the Venezeleion Hospital (4 graves), the Zapher Papoura cemetery (8 graves), through Sellopoulo (2 interments) and ending at the Mavro Spelio cemetery (1 interment). ${ }^{5}$ There is no particular piece of grave architecture favoured for these 'warrior graves'. Burials with weapons are found indifferently in pit caves, shaft graves and chamber tombs. Though the graves at Zapher Papoura and Sellopoulo were markedly richer than those elsewhere (KilianDirlmeier 1985), most 'warrior graves' were simple, accompanied by nothing more than weapons (bronze swords and spearheads), a razor and sometimes a pot. Where these pots can be dated, they all fall within the stylistic range of LMII-LMIIIA (Popham \& Catling 1974, 203-8). Sometimes graves are furnished with bronze vessels, sealstones and engraved rings. The engraved seals and rings all seem to be more or less contemporary with other objects in the grave (e.g. Popham \& Catling 1974, 217-25). Almost all the swords, even the most elaborately decorated, belong to Sandars Di class (Sandars 1963, 123-30 \& 146-8) and must then have been of more or less the same date as the pots, the sealstones and the bronze vessels. Though some antique (MMIII-LMI c. 1750-1500 BC) 'blossom bowls' have been found in some of the LMII-IIIA graves in the Zapher Papoura, Mavro Spelio and Sellopoulo cemeteries (Warren 1969, 1417), none of these antiques seem to have been deposited in any of the 'warrior graves'. Moreover, all the 
objects appear to be 'Minoan' - there are few if any imports.

Two points should be stressed here. First, though no osteological study has been made of these 'warrior graves' it is at least clear that not all of them were burials of adult men. Burial II at Sellopoulo grave 4 for example (Popham \& Catling 1974, 202-3 \& 225-9) is clearly a juvenile, but is still buried with an elaborate bronze sword, over $72 \mathrm{~cm}$ long, and a bronze dirk (Fig. 2). We seem again to be dealing with a situation where the status of a 'warrior' has been, not achieved, but ascribed. ${ }^{6}$ Secondly, though most finds seem to have been in good condition, and, like the bodies they accompanied, were whole and intact when they were interred, there are one or two departures from mainland practice. Some of the swords at least seem to have been deliberately damaged - possibly no B25 from Sellopoulo (Popham \& Catling 1974, 226-9) and certainly the sword from Mavro Spelio grave XVIII (Forsdyke 1927, 282).

\section{'Warrior graves' in the Early Iron Age}

Burial with weapons was much rarer in LMIIIB and early LMIIIC Knossos. The nearest we approach the weapon burial ritual in this period are two graves with knives from the Upper Gypsades (Hood et al. 1959). It is difficult then to describe how the situation gradually changed. Nonetheless it is instructive to contrast this Late Bronze Age pattern with that to be found in Subminoan (c. 1050-950 BC) and Early Protogeometric (c. 950-900 вс) times. There are a number of 'warrior graves' from this period. Of the much-damaged tombs from the North Cemetery, T.186 seems to be reasonably representative. This was a 'pit cave' containing the cremated remains of a man, accompanied by a stirrup jar, whetstone, bronze spearhead and phalara, and an iron dirk or knife (Coldstream \& Catling 1996, 190-91; Musgrave 1996, 692). The iron dirk (one of the earliest) appears to have been deliberately broken. A number of such graves were more elaborately furnished. Tomb 201, dating to c. $1050 \mathrm{BC}$, stands out. This contained the cremated remains of at least two individuals, male and female (Musgrave 1996, 692). Grave goods included bronze arms and armour (sword, spearhead, phalara) and an iron knife (Coldstream \& Catling 1996, 191-5). As in T.186, the sword appears to have been deliberately damaged or 'killed' in the course of the funeral ceremony. More spectacular still is the bronze four-sided Cypriot stand, found in eightyfive pieces. As one scholar observed (Coldstream \& Catling 1996, 194), 'the stand was probably laid on

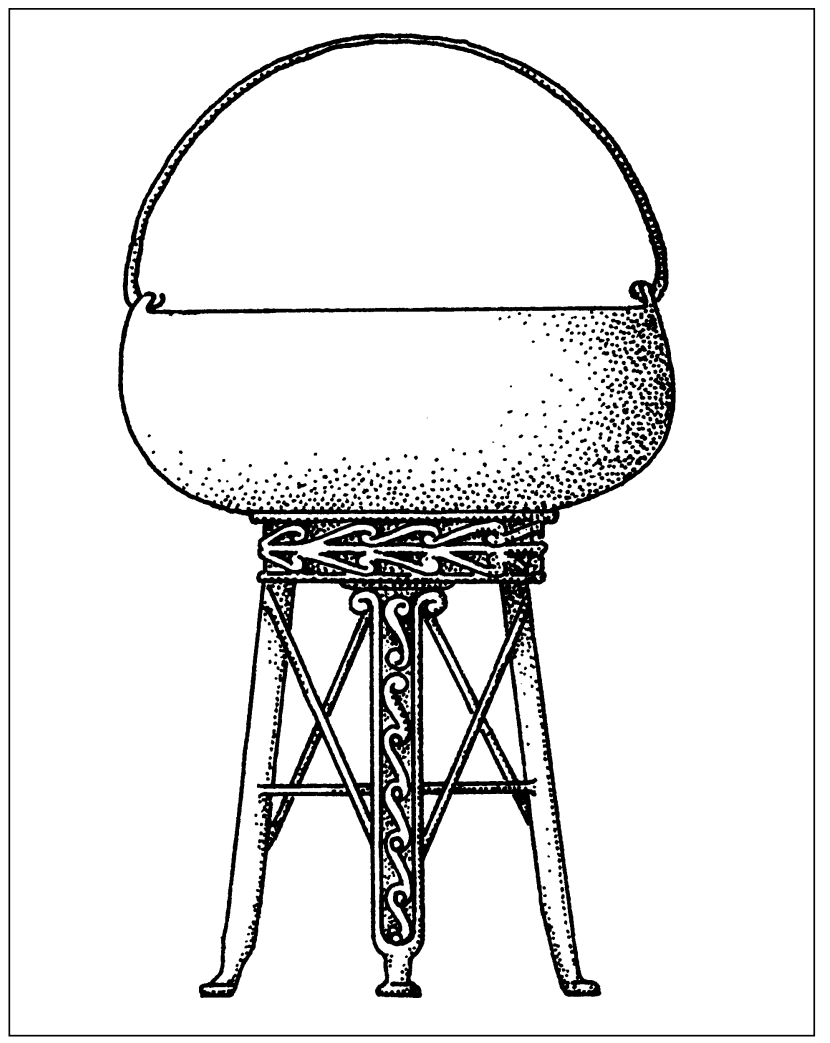

Figure 3. Rod tripod and cauldron from Fortetsa tomb XI, Fortetsa no. 188 (Brock 1957, pl. 13, 220). (Courtesy of Anthony Snodgrass.)

the body, for it seems to have been at the heart of the fire'. Body and grave goods were, it seems, burnt and broken together.

Cypriot bronzework has also been found in association with other 'warrior graves' in Knossos. A Cypriot rod tripod (Fig. 3) with cauldron was found in Fortetsa tomb XI, a tomb which has two cremations (in urns 3 and 14) clearly associated with weapons (Brock 1957, 18-22). ${ }^{7}$ Cypriot bronzework of this kind has always been controversial. Hector Catling has consistently argued that all rod tripods and foursided stands (or at least all of those found in Greece) are the products of a Cypriot bronze workshop active in the thirteenth and earlier part of the twelfth centuries $\mathrm{BC}$. Their style and iconography is too homogeneous, and the bronzeworking skills required for their manufacture too sophisticated for them to have come from anything other than a single workshop. ${ }^{8}$

Other scholars have begged to differ, pointing out that there is a Western Mediterranean group of tripod stand which were clearly later in date (Lo Schiavo et al. 1985). Matthäus in particular has ar- 


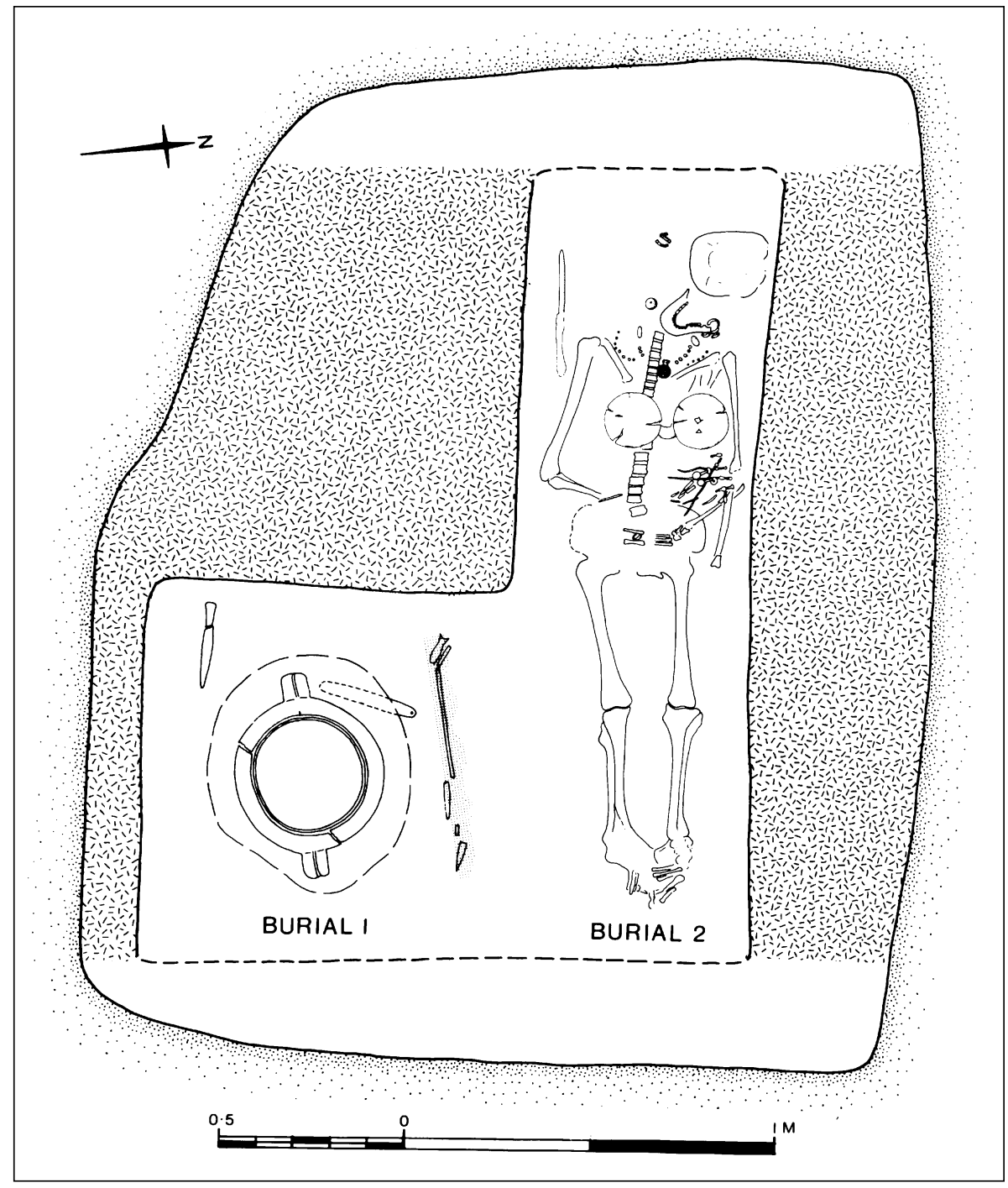

Figure 4. Burials beneath the 'heröon' at Lefkandi, Toumba. On the left the male inurned cremation, with sword; on the right the female inhumation (Popham et al. 1993, pl. 13). (Courtesy of the British School at Athens.)

gued for production being continued in later workshops for several centuries after 1200 вС (Matthäus 1985, 299-309; 1988). All one can say in defence of Catling's thesis is that, for the most part, the tripods and stands found in Aegean contexts resemble those found in Cyprus quite closely, and the West Mediterranean group not at all. Of the tripods and stands found in Cyprus itself, none date to later than Late Cypriot IIIC, and most come from much earlier contexts. The possibility of such objects acquiring 'biographies' was not something that either Catling or Matthäus explicitly considered, but such a possibility obviously strengthens Catling's hand. There are other circumstantial reasons for preferring Catling's dating. Cypriot tripods and stands are not the only antiques that appear frequently in Early Iron Age graves. At least one Cypriot bronze amphoroid krater and several Egyptian lotus-handled jugs seem to have been quite old at the time of their final deposition (see below). Moreover, in Homer tripods clearly move in the same elevated social circles as the silver kraters mentioned above. Though they are never described in 'biographical' terms, they too serve as prizes or gifts. ${ }^{9}$ From this perspective then, the stand from tomb 201 must then have been at least fifty, and the tripod from Fortetsa tomb XI at least one hundred years old at the time of their deposition. They were objects with histories. But the deposition of such antiques was only a secondary feature of this new EIA pattern. There seems to be a new requirement not only to burn the bodies of the dead, but to break or otherwise ostentatiously destroy many of the objects, particularly the weapons, buried with them.

This pattern was not unique to Knossos. By around 900 BC the practice of 'killing' swords, specifically the custom of bending an iron sword around a neck-handled amphora containing the cremated remains of man, had become quite common in Athens (Blegen 1952; Coldstream 1977, 30-32; Whitley 1991b, 11637). But in tenth- or ninth-century Athens, few exotica and no antiques are to be found in graves. ${ }^{10}$ For close parallels to Knossos we have to look towards Lefkandi. Lefkandi has plenty of warrior graves, most dating to the century fifty years either side of 900 BC. Toumba tomb 14,1 can be taken as representative. This is a cremation of a man in a neck-handled amphora accompanied by a 'killed' sword (Popham et al. 1980, 175-6; Musgrave 1980, 434). As in Knossos, there are a number of much more richly-furnished 
graves of this type, the bestknown of course being the 'hero of Lefkandi', found beneath the large building at Lefkandi, Toumba (Popham et al. 1993, x \& 19-22). This is in fact a double burial. On the left is a richly-furnished extended inhumation of a woman, whose grave goods included a Babylonian pendant with beads of gold, which was probably manufactured around 2000 ВС and must therefore have been almost a millennium old at the time of its deposition (Popham 1994, 15). Beside her was the male 'hero', whose cremated remains were found wrapped in cloth and contained within a Cypriot bronze amphoroid krater, accompanied by a killed sword and a spearhead (Fig. 4). Like the stand from T.201 at Knossos, this krater (Figs. 5 \& 6) appears to have been between one hundred and one hundred and fifty years old at the time of its deposition sometime around $1000 \mathrm{BC}^{11}$ This is by no means the only example of the deposition of antiques in 'warrior' graves. The Late Protogeometric Toumba tomb 39 was another grave with weapons, which also contained (amongst other things) bronze wheels, and an 'Egyptian' lotus-handled jug (Fig. 7) (Popham et al. 1982, 216-20; Popham \& Lemos 1996, pl. 43).

These lotus-handled bronze jugs have recently become almost as controversial as the Cypriot vessels. Jane Carter (1998) has argued that jugs of this type must too have been antiques at the time of their interment, since the best Egyptian parallels for such jugs date to the XVIIIth and

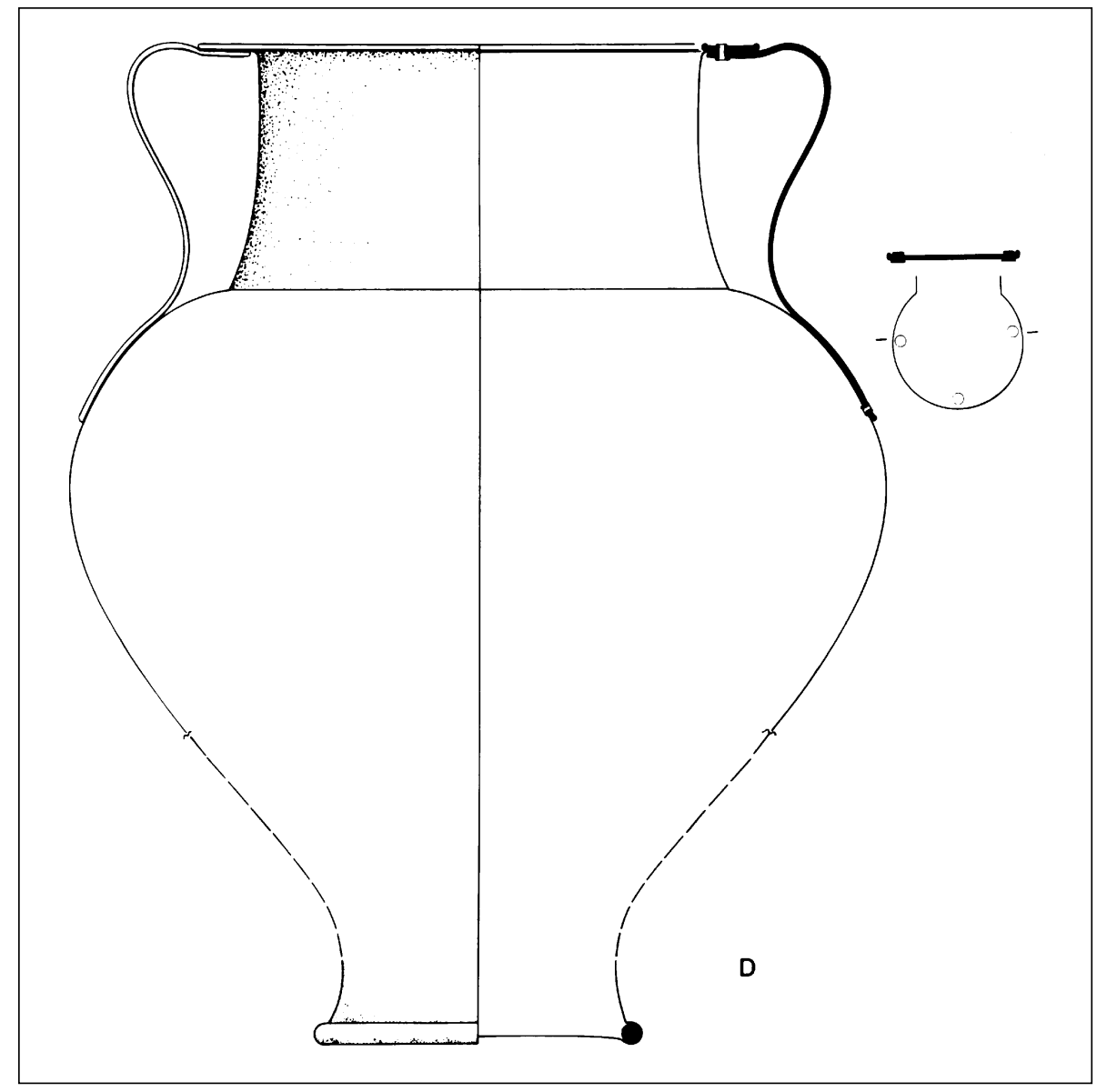

Figure 5. Bronze amphoroid krater used as urn for the male cremation, side view (Popham et al. 1993, pl. 18). (Courtesy of the British School at Athens.)

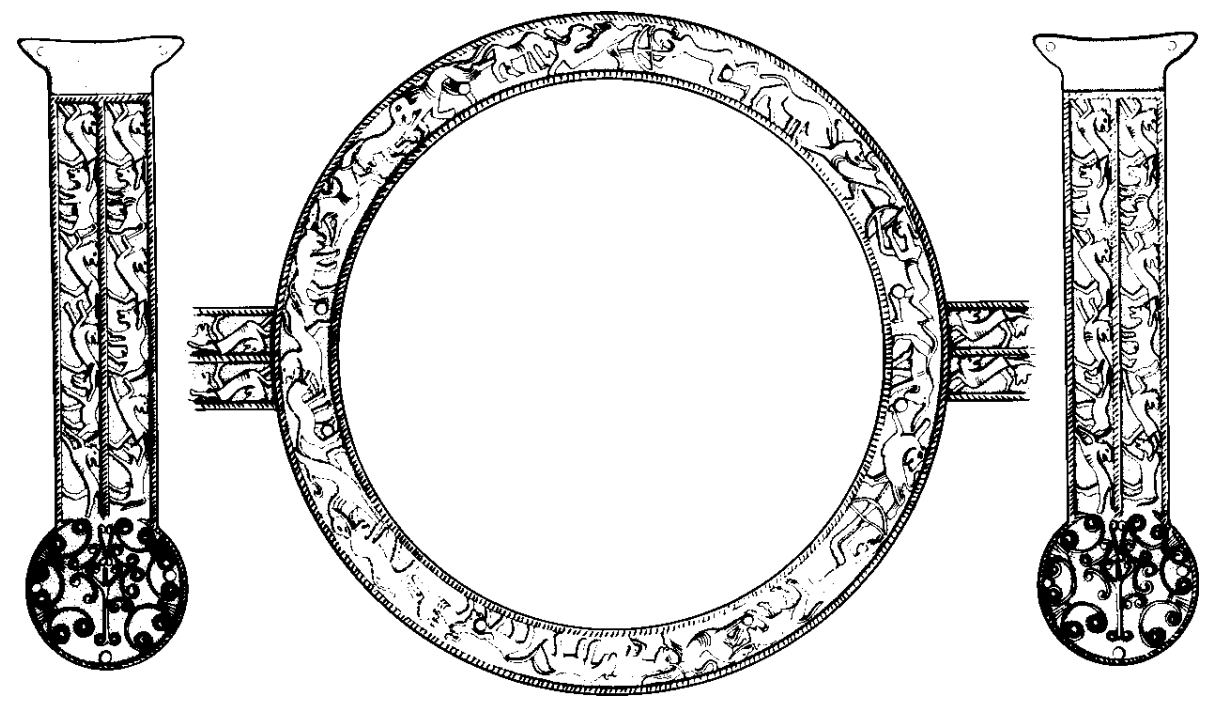

Figure 6. Same krater, top view, showing decoration on rim and handles (Popham et al. 1993, pl. 19). (Courtesy of the British School at Athens.) 


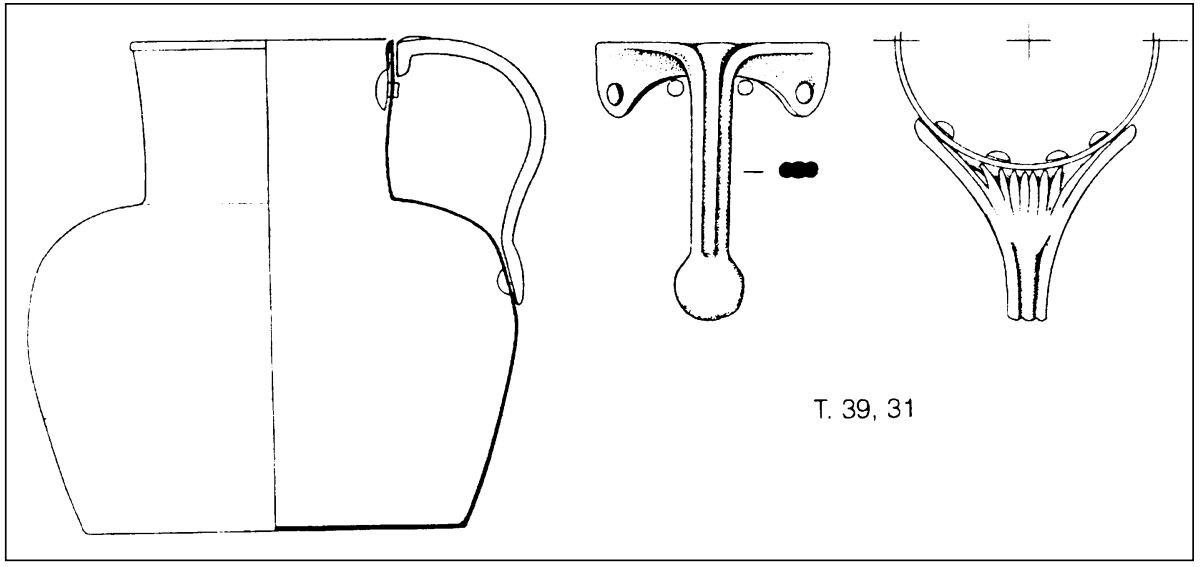

Figure 7. Egyptian or Phoenician lotus-handled jug $(T .39,31)$ from Toumba tomb 39 at Lefkandi (Popham \& Lemos 1996, pl. 132). (Courtesy of the British School at Athens.)

XIXth dynasties (Radwan 1983, 133-7). If so, that would make these objects between 500 and 250 years old when they were placed in graves in Lefkandi or Knossos (Catling \& Catling 1980, 248-51; Catling $1996 b, 565)$. It is possible, however, that these jugs are not of Egyptian manufacture, but rather Phoenician copies, in which case they are much harder to date (Catling 1996b, 565). But, even if they are Phoenician or Canaanite rather then Egyptian, they may still have been antiques at the time of their deposition. Recent research has shown that the manufacture of these Levantine 'imitations' begins in the thirteenth century вС, much earlier than was previously thought. ${ }^{12}$ So, if Catling is to be consistent in his arguments, the extended period over which such objects were deposited is an argument for their being antiques. Whatever their date, these were certainly not the oldest objects to be found in Lefkandiot 'warrior graves'. Toumba tomb 79 (of Subprotogeometric II date, $c$. 870-830 BC), another cremation in a bronze urn accompanied by a killed sword, contained a Near Eastern cylinder seal which must have been made around 1800 вс (Popham \& Lemos 1995). ${ }^{13}$

Antiques such as these have usually been considered 'heirlooms'. An heirloom is an object retained within the same family for several generations, normally being passed down from mother to daughter or father to son. As ethnography shows, not all biographical objects need be heirlooms. The silver kraters mentioned in the Homeric poems are not heirlooms in this strict sense. Rather than being passed down through the generations of one family, these objects circulate within the elevated circles of the Homeric aristocracy. In the case of objects which are one, two or three generations old at the time of their deposition (such as the amphoroid krater from Lefkandi or the wheeled stand from Knossos) the term 'heirloom' is not unreasonable. But if Jane Carter (1998) is right about the lotus-handled jugs, then to suppose that the same object was retained within a family for between seven and fourteen generations seems a little far-fetched. Here, the 'heirloom' hypothesis wears a little thin. The same argument applies, a fortiori, to the Near Eastern cylinder seal and the Babylonian necklace found in graves in Lefkandi. My point is not that such objects were never heirlooms, but that to explain their survival from the eighteenth, sixteenth or thirteenth centuries BC until the tenth or ninth an additional hypothesis is necessary. It is better to see these things as forming part of a restricted sphere of exchange, more often than not being retained within the same family for a number of generations, but also passing from one individual to another as a gift or payment of ransom. It is in these ways that objects might have acquired their histories, their biographies.

\section{Conclusion}

The contrast between the 'warrior graves' in Late Bronze Age Knossos on the one hand and Early Iron Age Knossos and Lefkandi on the other indicates much more than a change in custom. It is evidence for a new conception of masculinity and a new social order. Late Bronze Age warrior graves are not greatly differentiated from other burials. Both bodies and objects are, for the most part, buried whole and intact. Early Iron Age 'warrior graves' by contrast are marked out by the ostentatious destruction of bodies and objects in the funeral ceremony. Certain exceptional graves are accompanied by antiques. These are objects which are likely to have acquired 'biographies' of their own, 'biographies' which, in their deposition or destruction in a burial ceremony, are brought to a close. The object 'dies' with the person it honours.

Many scholars have noted that the manner in which some of these 'warriors' were buried closely parallels the description of the funeral ceremonies of 
the heroes Patroclus and Hector in the Iliad. ${ }^{14}$ This observation has often prompted a kind of chickenand-egg debate as to which came first: the story or the custom. Such literal-mindedness gets us nowhere. We have to remember that funerals are as much occasions in which identities are created or reinforced as they are straightforward outcomes or reflections of contemporary ideas, beliefs or social structures. Burial ceremonies can help to constitute new kinds of personal and cultural identities (e.g. J. Thomas 1991; Parker Pearson 1999). To bury a man as a warrior (whether or not he actually was one) is therefore to make ideological claims about status, hierarchy, authority and gender.

Gender is a complex issue. Recent work has emphasized that gender is not sex; that is, it is not to be equated with a natural, biological division between adult men and adult women. Rather, gender is 'the cultural interpretation of sexual difference that results in the categorisation of individuals, artefacts, spaces and bodies' (Gilchrist 1999, xv). ${ }^{15}$ Gender is not a structural universal, an eternal binary, but rather a dimension of identity that derives as much from one's stage in life as from one's genotype. Other work has shown how gender identities change through the life cycle, and how the life cycles of objects relate to the life cycles of individuals (Derevenski 1997). All this has a direct bearing on Early Iron Age Greece. I have argued elsewhere that it is a mistake to see gender roles in Early Iron Age Greece in terms of a simple opposition between 'masculine' and 'feminine' (Whitley 2000). Instead, the picture we seem to get from a survey of burial practices is that of an age/gender polarity. At one end of this spectrum are young, sexually undifferentiated children, invariably inhumed and usually interred in pithoi or other vessels; at the other, the ostentatious burning and breaking of men and weapons. Adult women (who are sometimes cremated, sometimes inhumed) seem to fall between these two poles. This new gendered division seems to have been created at the very beginning of the Iron Age, and plays itself out in different ways in different regions of Greece. Grave T.201 in Knossos and the burial of the 'hero of Lefkandi' mark the moment when this new conception was invented.

What then was this conception, at least as far as 'warrior graves' are concerned? The polarity I have outlined implies that to be a man is the opposite of being a child, and that 'being a man' ideally means being a warrior. In the Bronze Age, a 'warrior' formed part of a range of male identities. In this new order, however, warriors are obliged to die, or at least be buried - literally and metaphorically — in a blaze of glory. New identities are brought about in a variety of ways. Ritual action and burials are important, but hardly more so than tales or stories. Indeed, it is difficult to see how a certain kind of burial could have been effective unless it formed part of a wider 'poetics of manhood'. The paradigmatic story of what it is to be, live and die a warrior is of course the Iliad. It is, I think, no coincidence that this narrative closes with the burial of the indirect (Patroclus) and the direct (Hector) victims of Achilles' wrath. Their burials are similar because their status in the narrative hero-victims - is similar. There is no attempt by Homer to differentiate them, in death, by race or ethnic background. Their burials are ostentatious and destructive, a fitting end to a meditation on 'the hero'.

For the past fifty years or so, discussion of the relationship between Homer, history and archaeology has concentrated on the question of 'Homeric society'. The Homeric poems have been interrogated for their (unconscious) references to social and institutional facts which must, it has been argued, have formed part of the poet's world (Finley 1979). Debates have focused on whether these facts make up a coherent social whole, and how they are to be understood in relation both to archaeological evidence and ethnographic analogy (e.g. Qviller 1981; Whitley 1991a). This approach certainly has its value, but recent scholarship has emphasized its limitations. Society is not simply a structure composed of institutions, but a process, a 'conversation' between values and practices (I. Morris 1997; 2000). Anthropology too has shown how 'biographical objects' relate only indirectly to social institutions, and much more immediately to the narratives of peoples' lives (Hoskins 1998). It is in this light that we should look at both object biographies and warrior graves. Early Iron Age warrior graves represent the convergence and the closure of two kinds of narrative; the personal story of the man buried; and the 'cultural biography' of the older and more valuable objects, such as a Cypriot wheeled stand or amphoroid krater, buried with him. There is then a homology between the narrative structure of the Iliad and the narrative being created (and brought to a close) in the funerals of 'warriors', a homology reinforced by the closure of the cultural biography of the objects. It is this convergence of personal and material narratives that serves to create a new cultural ideal: the warrior as 'hero'.

\section{Acknowledgements}

This article was first presented as a seminar paper in 
Oxford in 1999. Other versions have been given at Birmingham and Cardiff. I would like to thank Anthony Snodgrass and the British School at Athens for permission to reproduce drawings, and Christina Hatzimichael, Anthony Snodgrass, Hector Catling, Robin Osborne and the anonymous referees for the Cambridge Archaeological Journal for comments on earlier drafts of this paper. They must excuse me if, through obstinacy, I have not followed all of their recommendations. Howard Mason was, as ever, responsible for some of the excellent drawings. I must apologize to my colleagues in the Anglo-Saxon field (H. Härke, Howard Williams and John Hines) for not making more use of their guidance on some intriguing parallels with the material discussed here.

\section{Notes}

1. The meaning of heros in the Homeric poems has been much discussed. I agree with West's (1978, 370-73) view that, in Homer at least, one of its principal connotations must have been 'warrior'. It has, of course, other meanings as well, which become more prominent in Greek history after the eighth century BC, as recent debates on 'hero cults' (Antonaccio 1995b, 14597; Whitley 1995) have shown.

2. That having been said, the potential of the idea of objects having biographies for the study of post-Roman/early medieval Britain has yet to be realized. There are certain obvious candidates for this kind of analysis. The 'Celtic' hanging bowls which turn up in numerous Anglo-Saxon graves, in particular the ship burial at Sutton Hoo (Bruce-Mitford 1983, 202-95) are an obvious case in point. These objects were clearly old at the time of their deposition, and seem to have been manufactured far from their 'final resting place'. It is disappointing to find that most recent discussions of these objects (e.g. Brenan 1991; Geake 1999) have focused narrowly on questions of relative chronology, and not on their 'social lives' or their role in burial. The recent tendency to down-date these objects may be misplaced.

3. The Shaft Graves remain as controversial now as when they were first excavated by Schliemann (1880). Though it is at least clear that those buried in the Shaft Graves were a very unrepresentative slice of the population of the MHIII-LHII Argolid (KilianDirlmeier 1986), the overall Shaft Grave phenomenon remains mysterious. The grave symbolism, particularly of the 'warrior graves', is highly redundant. Such ostentatious destruction of wealth in burial may however relate to a need to create a new kind of authority. For the most recent discussion, see Rutter (2001, 137, 139-41 \& 154) with references.

4. The chamber tombs at Mycenae are tomb 78 (Tsountas 1897, 105-7) and 81 (Tsountas 1897, 107-9), both being burials with swords. The four tombs at Prosymna are tomb XXV (Blegen 1937, 86-92), tomb XXXVII (Blegen 1937, 123-8), tomb III (Blegen 1937, 180-85) and tomb XLIII (Blegen 1937, 185-90). With the exception of the sword in XXXVII, all the weapons interred are daggers. Few if any of these weapons can be associated with a particular, individual interment. KilianDirlmeier's statement that 'the sword as a grave gift characterizes the warrior quality of the dead, as at the same time it had the significance of a status symbol indicating a rather high level of social ranking' (KilianDirlmeier 1990, 158) therefore requires extensive qualification.

5. In more detail, the 'warrior graves' are:- the Acropolis grave (Evans 1935, 849-50); two graves at Ayios Ioannis (Hood 1956; Hood \& de Jong 1952, 245-6 \& 261-2); graves I, II, III and V at the Venezeleion hospital (Hood \& de Jong 1952, 248-77); the eight graves at Zapher Papoura - tomb 14 (Evans 1905, 424-35), tomb 36 (Evans 1905, 441-9), tombs 42, 43 and 44 (Evans 1905, 449-53), tomb 55 (Evans 1905, 456-7), and tombs 95 \& 98 (Evans 1905, 473-7); burials I and II in Sellopoulo grave 4 (Popham \& Catling 1974); and tomb XVIII in the Mavro Spelio cemetery (Forsdyke 1927, 282). The most recent overviews are by KilianDirlmeier (1986) and by Preston (1999).

6. There seems to be another case of a child's 'warrior grave' (i.e a child buried with a sword far too big for him) from the Phourni cemetery in nearby Archanes (Sakellarakis 1966, 182-3).

The argument here assumes some familiarity with the debate about the relationship between mortuary practices and social forms initiated by Binford (1972) and Saxe (1970). For the latest 'bulletin' on this debate see Parker Pearson (1999).

7. Other examples of rod tripods in Early Iron Age tombs at Knossos include one from Hogarth's tomb 3 (Hogarth 1900, 82-5) and one other from N. Cemetery tomb 100 (Coldstream \& Catling 1996, 132-8). For the most recent discussion of these 'imports' see Catling 1996b; Hoffman 1997, 95-9, 116-20. Hoffman believes that all these rod tripods are of Cretan, not Cypriot, manufacture.

It has often been suggested that the recrudescence of the 'warrior grave' in Knossos in late LMIIIC/early Subminoan times, after an apparent gap in LMIIIB, is due to the coming of 'intrusive elements' into Knossos. The apparent similarity between these burials in Knossos and those at Lefkandi (Popham et al. 1993) and Tiryns grave XXVIII (Verdhelis 1963, 10-24) can be explained by their northern character (Catling 1995; 1996a). The idea that innovation must be due to ethnic change is a very old one. In any case, if some of these 'elements' 'intruded' from elsewhere, it was unlikely to have been the 'Dorian' north. Cremation seems to have originated in 'Eteocretan' East Crete (Popham 1986; Snodgrass 1971, 187-91). In any case, the practice of deliberately damaging swords in burials seems to have originated in Knossos itself (see above), whence it may have spread to other parts of Greece. 
8. This is an argument put forward with extraordinary consistency over the years, despite vigorous criticism from many quarters. See Catling (1964, 191-225; 1984; 1996a, 517-18; 1996b, 568-9). Recently, other scholars have suggested that the manufacture of rod tripods might have begun much earlier, and not in Cyprus, but in Eastern Crete in the LMIIIB period (Hemingway 1996, 243-50). Catling (1997) remains unconvinced.

9. Tripods are used as prizes in games (Iliad XXIII.262-5; XI.700-1) and as gifts (Iliad VIII.287-91; Odyssey XIII.13). Elsewhere they have a more practical purpose - they are used for heating water (Odyssey. VIII.435; Iliad XVIII.344-50). In Iliad IX.122 seven 'unburnt' (i.e. unused) tripods form part of the bribe offered to Achilles by Agamemnon in order to persuade Achilles to return to battle. That tripods were valued new rather than old in Homer may be an obstacle to my 'biographical' thesis. Homer, however, does not distinguish between kinds of tripod, as the archaeologist can. It is not clear whether the Cypriot rod tripods mentioned here were ever used to heat water. Such a function may better suit the class of Geometric tripods found in large numbers at Olympia (e.g. Maass 1978) and elsewhere.

10. The Pnyx grave with a Cypriot rod tripod (Brückner 1893) dates to Late Geometric I (c. 770-740 вс).

11. For the krater itself, see Catling 1993. For parallels from Cyprus itself, Catling 1964, 156-61; Matthäus $1985,228-32$. The burials are dated by the pottery from the so-called 'heröon' above. Unfortunately, these deposits are not closely datable. All that is certain is that the structure cannot be later than $950 \mathrm{BC}$ (R. Catling \& Lemos 1990, 91-5).

Ever since its discovery, the nature of the whole Toumba complex of burials, structure and mound has been controversial. For the latest on this, see Popham et al. 1993, 97-101; Antonaccio 1995a; I. Morris 2000, 195-256.

12. The evidence consists of a bronze jug from the Canaanite cemetery of Deir el Balah (Dothan 1979, 66-8 \& pls. 148-9; Gershuny 1985, 19n.127). For a recent re-appraisal of Phoenician and Levantine Late Bronze Age and Early Iron Age bronzework, see Falsone 1988, esp. p. 234.

13. There is also the possibility that other Near Eastern imports in Lefkandi might have been, if not heirlooms of great antiquity, at least 'entangled objects' which may have had a bearing on the statements about identity being made in the burial ceremony. The 'Phoenician' bronze bowls from Toumba tombs 70 and 55 (Popham 1995; Popham \& Lemos 1996, pls. 133 \& 134) may fall into this category. Unfortunately such bowls are, for the most part, not closely datable (Markoe 1985), and we cannot even speculate whether or not they were antiques.

14. For example Antonaccio 1995a. The burial of Patroclus is described in Iliad XXIII.161-257; the more modest funeral of Hector in Iliad XXIV.782-804.

15. Of course, there are more nuanced definitions of gen- der. But most theorists agree (mostly following Moore $1988,12-41)$ that gender is as much a cultural construct as a biological 'given'.

$$
\begin{array}{r}
\text { James Whitley } \\
\text { School of History } \mathcal{E} \text { Archaeology } \\
\text { Cardiff University } \\
\text { PO Box } 909 \\
\text { Cardiff } \\
\text { CF10 3XU } \\
\text { Email: WhitleyA@Cardiff.ac.uk }
\end{array}
$$

\section{References}

Andronikos, M., 1994. Vergina: the Royal Tombs and the Ancient City. Athens: Ekdotike Athenon.

Antonaccio, C.M., 1995a. Lefkandi and Homer, in Homer's World, eds. Ø. Andersen \& M. Dickie. Bergen: P. Åstrom, 5-27.

Antonaccio, C.M., 1995b. An Archaeology of Ancestors: Tomb Cult and Hero Cult in Early Greece. Lanham (MD): Rowman \& Littlefield.

Appadurai, A., 1986a. Introduction: commodities and the politics of value, in Appadurai (ed.) 1986b, 3-63.

Appadurai, A. (ed.), 1986b. The Social Life of Things: Commodities in Cultural Perspective. Cambridge: Cambridge University Press.

Åström, P., 1977. The Cuirass Tomb and Other Finds at Dendra. Göteberg: Paul Åströms Forlag.

Bennet, J., 1997. Homer and the Bronze Age, in Morris \& Powell (eds.), 511-33.

Binford, L.R., 1972. Mortuary practices: their study and their potential, in An Archaeological Perspective, ed. L. Binford. New York (NY): Academic Press, 20843.

Blegen, C.W., 1937. Prosymna: the Helladic Settlement Preceding the Argive Heraeum. (2 volumes.) Cambridge: Cambridge University Press.

Blegen, C.W., 1952. Two Athenian grave groups of about 900 вс. Hesperia 21, 279-94.

Brenan, J., 1991. Hanging Bowls and Their Contexts: an Archaeological Survey of their Socio-Economic Significance from the Fifth to the Seventh Centuries AD. (BAR British Series 220.) Oxford: Tempus Reparatum.

Brock, J.K., 1957. Fortetsa: Early Greek Tombs near Knossos. Cambridge: Cambridge University Press.

Bruce-Mitford, R., 1983. The Sutton Hoo Ship Burial, vol. 3: Late Roman and Byzantine Silver, Hanging Bowls, Drinking Vessels, Cauldrons and Other Containers; Textiles, the Lyre, Pottery, Bottles and Other Items. London: British Museum.

Brückner, A., 1893. Ein attischer Grabfund der geometrischen Periode. Mitteilungen des deutschen archäologischen Instituts, athenische Abteilung 18, 414-15.

Carter, J., 1998. Egyptian bronze jugs from Crete and Lefkandi. Journal of Hellenic Studies 118, 172-7.

Casson, S., 1925. Excavations in Macedonia II. Annual of the British School at Athens 26 (1923-25), 1-29. 
Catling, H.W., 1964. Cypriot Bronzework in the Mycenaean World. Oxford: Clarendon Press.

Catling, H.W., 1984. Workshop and heirloom: prehistoric bronze stands in the East Mediterranean. Report of the Department of Antiquities, Cyprus 1984, 70-91.

Catling, H.W., 1993. The bronze amphora and burial urn, in Popham et al. (eds.), 81-96.

Catling, H.W., 1995. Heroes returned? Subminoan burials from Crete, in The Ages of Homer: a Tribute to Emily Townsend Vermeule, eds. J.B. Carter \& S.P. Morris. Austin (TX): University of Texas Press, 123-36.

Catling, H.W., 1996a. The objects other than pottery in the Subminoan tombs, in Coldstream \& Catling (eds.), 517-37.

Catling, H.W., 1996b. The Dark Age and later bronzes, in Coldstream \& Catling (eds.), 543-74.

Catling, H.W., 1997. Minoan metalworking at Palaikastro: some questions. Annual of the British School at Athens 92, 51-8.

Catling, H.W. \& E.A. Catling, 1980. Objects of bronze, iron and lead, in Popham et al. (eds.), 231-64.

Catling, R.W.V. \& I.S. Lemos, 1990. Lefkandi II.1: the Protogeometric Building at Toumba: the Pottery. (BSA Suppl. 22.) London: British School at Athens.

Coldstream, J.N., 1977. Geometric Greece. London: Ernest Benn.

Coldstream, J.N. \& H.W. Catling (eds.), 1996. Knossos North Cemetery: Early Greek Tombs. (4 volumes, 2 text, 2 plates. (BSA Supplementary volume 28.) London: British School at Athens.

Deger-Jalkotzy, S., 1999. Military prowess and social status in Mycenaean Greece, in Laffineur (ed.), 121-31.

Derevenski, J.S., 1997. Engendering children, engendering archaeology, in Invisible People and Processes: Writing Gender and Childhood into European Archaeology, eds. J. Moore \& E. Scott. Leicester: Leicester University Press, 192-202.

Dothan, T., 1979. Excavations at the Cemetery of Deir-elBalah. (Qedem: Monographs of the Institute of Archaeology 10.) Jerusalem: Hebrew University of Jerusalem.

Driessen, J. \& C. MacDonald, 1984. Some military aspects of the Aegean in the late fifteenth and early fourteenth centuries BC. Annual of the British School at Athens 79, 49-74.

Edmonds, M., 1999. Ancestral Geographies of the Neolithic: Landscapes, Monuments and Memory. London: Routledge.

Evans, A., 1905. The prehistoric tombs of Knossos. Archaeologia, or Miscellaneous Tracts Relating to Antiquity LIX, 391-562.

Evans, A., 1935. The Palace of Minos at Knossos, vol. IV. London: Macmillan.

Falsone, G., 1988. Phoenicia as a bronzeworking centre in the Iron Age, in Bronzeworking Centres of Western Asia, c. 1000-539 BC, ed. J. Curtis. London \& New York (NY): Kegan Paul International, 227-50.

Finley, M.I., 1979. The World of Odysseus. Revised edition. Harmondsworth: Penguin.
Forsdyke, E.J., 1927. The Mavro Spelio cemetery at Knossos. Annual of the British School at Athens 28 (1926-7), 243-96.

Geake, H., 1999. When were hanging bowls deposited in Anglo-Saxon graves? Medieval Archaeology 43, 1-18.

Gershuny, L., 1985. Bronze Vessels from Israel and Jordan. (Praehistorische Bronzefunde II.6.) Munich: C.H. Beck.

Gilchrist, R., 1999. Gender and Archaeology: Contesting the Past. London: Routledge.

Gosden, C. \& Y. Marshall, 1999. The cultural biography of objects. World Archaeology 31(2), 169-78.

Härke, H., 1990. 'Warrior graves?' The background of the Anglo-Saxon weapon burial ritual. Past and Present 126, 22-43.

Härke, H., 1992. Angelsächsiche Waffengräber des 5. Bis 7. Jahrhunderts. Cologne: Rheinland Verlag.

Härke, H., 2000. The circulation of weapons in AngloSaxon society, in Rituals of Power: From Late Antiquity to the Early Middle Ages, eds. F. Theuws \& J.L. Nelson. Leiden: E.J. Brill, 377-99.

Hemingway, S., 1996. Minoan metalworking in the postpalatial period: a deposit of metallurgical debris from Palaikastro. Annual of the British School at Athens 91, 213-52.

Hoffman, G.L., 1997. Imports and Immigrants: Near Eastern Contacts with Iron Age Crete. Ann Arbor (MI): University of Michigan Press.

Hogarth, D.W., 1900. Knossos II: early town and cemeteries. Annual of the British School at Athens 6, 70-85.

Hood, M.S.F., 1956. Another warrior grave at Ayios Ioannis near Knossos. Annual of the British School at Athens 51, 81-99.

Hood, M.S.F. \& P. de Jong, 1952. Late Minoan warrior graves from Ayios Ioannis and the New Hospital site at Knossos. Annual of the British School at Athens 47, 243-77.

Hood, M.S.F., G. Huxley \& N. Sandars, 1959. A Minoan cemetery on the Upper Gypsades. Annual of the British School at Athens 53-4 (1948-59), 194-262.

Hoskins, J., 1998. Biographical Objects: How Things Tell the Stories of People's Lives. London: Routledge.

Kilian-Dirlmeier, I., 1985. Noch einmal zu den 'Kriegergräbern' von Knossos. Jahrbuch des römisch-germanisch Zentralmuseums Mainz 32, 196-214.

Kilian-Dirlmeier, I., 1986. Beobachtungen zu den Schachtgräbern von Mykenai und zu den Schmuckbeigaben mykenischer Männergräber: Untersuchungen zur socialstruktur in späthelladischer Zeit. Jahrbuch des römisch-germanisch Zentralmuseums Mainz. 33(1), 15998.

Kilian-Dirlmeier, I., 1990. Remarks on the non-military functions of swords in the Mycenaean Argolid, in Celebrations of Death and Divinity in the Bronze Age Argolid, eds. R. Hägg \& G.C. Nordqvist. Stockholm: Paul Åströms Forlag, 157-61.

Kopytoff, I., 1986. The cultural biography of things: commoditization as process, in Appadurai (ed.) 1986b, 64-91. 
Laffineur, R. (ed.), 1999. Polemos: Le Contexte Guerrier en Égée à L'Âge du Bronze. (Aegeaum 19, 2 volumes.) Liège: Université de Liège.

Langdon, S., 2001. Beyond the grave: biographies from early Greece. American Journal of Archaeology 105, 579-606.

Lo Schiavo, F., E. Macnamara \& L. Vagnetti, 1985. Late Cypriot imports to Italy and their influence on local bronzework. Papers of the British School at Rome 53, $1-71$.

Maass, M., 1978. Die geometrischen Dreifüsse von Olympia: Olympische Forschungen X. Berlin: Walter de Gruyter.

Markoe, G., 1985. Phoenician Bronze and Silver Bowls from Cyprus and the Mediterranean. (University of California Classical Studies 26.) Berkeley (CA): University of California Press.

Matthäus, H., 1985. Metallgefüsse und Gefassuntersätze der Bronzezeit, der geometrischen und archaïschen Periode auf Cypern. Munich: C.H. Beck.

Matthäus, H., 1988. Heirloom or tradition? Bronze stands of the second and first millennium $\mathrm{BC}$ in Cyprus, Greece and Italy, in Problems in Greek Prehistory: Papers Presented at the Centenary Conference of the British School at Athens, Manchester, April 1986, eds. E.B. French \& K.A. Wardle. Bristol: Bristol Classical Press, 285-300.

Moore, H., 1988. Feminism and Anthropology. Cambridge: Polity.

Morris, I., 1997. Homer and the Iron Age, in Morris \& Powell (eds.), 535-59.

Morris, I., 1998. Archaeology and Archaic Greek history, in Archaic Greece: New Approaches and New Evidence, eds. N. Fisher \& H. Van Wees. London: Duckworth, $1-91$.

Morris, I., 2000. Archaeology as Cultural History: Words and Things in Iron Age Greece. Oxford: Blackwell.

Morris, I. \& B. Powell (eds.), 1997. A New Companion to Homer. Leiden: E.J. Brill.

Morris, S.P., 1997. Homer and the Near East, in Morris \& Powell (eds.), 599-623.

Musgrave, J.H., 1980. The human remains from the cemeteries, in Popham et al. (eds.), 430-46.

Musgrave, J.H., 1990. The cremated remains from tombs II and III at Nea Mihaniona and tomb Beta at Derveni. Annual of the British School at Athens 85, 310-25.

Musgrave, J.H., 1996. The human bones, in Coldstream \& Catling (eds.), 677-702.

Papadopoulos, T.J., 1999. Warrior graves in Achaean Mycenaean cemeteries, in Laffineur (ed.), 267-74

Parker Pearson, M., 1999. The Archaeology of Death and Burial. Stroud: Sutton Publishing.

Persson, A.W., 1931. The Royal Tombs at Dendra near Midea. Lund: C.W.K. Gleerup.

Popham, M.R., 1986. A late Minoan IIIC pyxis in the Andreades collection. Oxford Journal of Archaeology 5, 157-64.

Popham, M.R., 1994. Precolonization: early Greek contact with the East, in The Archaeology of Greek Colonisa- tion: Essays Dedicated to Sir John Boardman, eds. G.R. Tsetskhadze \& F. De Angelis. Oxford: Oxford University Committee for Archaeology, 11-34.

Popham, M.R., 1995. An engraved Near Eastern bronze bowl from Lefkandi. Oxford Journal of Archaeology $14,103-7$.

Popham, M.R. \& H.W. Catling, 1974. Sellopoulo tombs 3 and 4, two late Minoan graves near Knossos. Annual of the British School at Athens 69, 195-257.

Popham, M.R. \& I.S. Lemos, 1995. A Euboean warrior trader. Oxford Journal of Archaeology 14, 151-7.

Popham, M.R. \& I.S. Lemos, 1996. Lefkandi III: the Early Iron Age Cemetery at Toumba: the Excavations of 1981 to 1994. (BSA Suppl. 29.) London: British School at Athens.

Popham, M.R., L.H. Sackett \& P.G. Themelis (eds.), 1980. Lefkandi I: the Iron Age Settlement: the Cemeteries. 2 volumes, text and plates. (BSA Suppl. 11.) London: Thames \& Hudson.

Popham, M.R., E. Touloupa \& L.H. Sackett (eds.), 1982. Further excavation at the Toumba cemetery at Lefkandi 1981. Annual of the British School at Athens 77, 213-48.

Popham, M.R., P.G. Calligas \& L.H. Sackett, 1989. Further excavation of the Toumba cemetery at Lefkandi, 1984 and 1986, a preliminary report. Archaeological Reports 35 (1988-89), 117-29.

Popham, M.R., P.G. Calligas \& L.H. Sackett, 1993. Lefkandi II.2: the Protogeometric Building at Toumba: the Excavation, Architecture and Finds. (BSA Suppl. 23.) London: British School at Athens.

Preston, L., 1999. Mortuary practices and the negotiation of social identities in LMII Knossos. Annual of the British School at Athens 94, 131-43.

Qviller, B., 1981. The dynamics of Homeric society. Symbolae Osloenses 56, 109-55.

Radwan, A., 1983. Die Kupfer- und Bronzegefässe Ägyptens (Von den Anfüngen bis zum Beginn der Spätzeit). (Praehistorische Bronzefunde II.2). Munich: C.H. Beck.

Rutter, J.B., 2001. The pre-palatial Bronze Age of the Southern and Central Greek mainland (with addendum), in Aegean Prehistory: a Review. American Journal of Archaeology, ed. T. Cullen. (Supplement I.) Boston (MA): Archaeological Institute of America, 95-155.

Sakellarakis, I.A., 1966. Anaskaphi Archanon. Praktika tis en Athinais Archaiologiki Etaireia 1966, 174-84.

Sandars, N.K., 1963. Later Aegean bronze swords. American Journal of Archaeology 67, 117-53.

Saxe, A.A., 1970. Social Dimensions of Mortuary Practices. Unpublished PhD thesis, University of Michigan, Ann Arbor.

Schliemann, H., 1880. Mycenae: a Narrative of Researches and Discoveries at Mycenae and Tiryns. New York (NY): Benjamin Blom. [Reprinted 1967.]

Snodgrass, A.M., 1971. The Dark Age of Greece. Edinburgh: Edinburgh University Press.

Themelis, P.G. \& Y.P. Touratsoglou, 1997. I Taphoi tou Derveniou. Athens: Ekdotiki tou Tameiou Archaiologikon Poron kai Apallotioseon.

Thomas, J., 1991. Reading the body: Beaker funerary prac- 
tice in Britain, in Sacred and Profane: Proceedings of a Conference on Archaeology, Ritual and Religion, Oxford 1989, eds. P. Garwood, D. Jennings, R. Skeates \& J. Toms. Oxford: Oxbow, 33-42.

Thomas, N., 1991. Entangled Objects: Exchange, Material Culture and Colonialism in the Pacific. Cambridge (MA): Harvard University Press.

Tilley, C., 1996. An Ethnography of the Neolithic: Early Prehistoric Societies in Southern Scandinavia. Cambridge: Cambridge University Press.

Tilley, C., 1999. Metaphor and Material Culture. Oxford: Blackwell.

Tsountas, C., 1897. Mitrai kai xiphi ek Mykenon. Archaiologiki Ephemeris 1897, 97-127.

Verdhelis, N.M., 1963. Neue geometrische Gräber in Tiryns. Mitteilungen des deutschen archäologischen Instituts, athenische Abteilung 78, 1-62.

Votokopoulou, I., 1986. Vitsa: Ta Nekrotapheia Mias Molossikis Komis. 3 vols. Athens: Ekdhosi tou Tameiou Archaiologikon Poron kai Apallotriseon.

Warren, P., 1969. Minoan Stone Vases. Cambridge: Cambridge University Press.

Weiner, A.B., 1992. Inalienable Possessions: the Paradox of Keeping-While-Giving. Berkeley (CA): University of California Press.

West, M.L., 1978. Hesiod: Works and Days: Edited with Pro- legomena and Commentary. Oxford: Clarendon Press. Whitley, J., 1991a. Social diversity in Dark Age Greece. Annual of the British School at Athens 86, 341-65.

Whitley, J., 1991b. Style and Society in Dark Age Greece. Cambridge: Cambridge University Press.

Whitley, J., 1995. Tomb cult and hero cult: the uses of the past in Archaic Greece, in Time, Tradition and Society in Greek Archaeology: Bridging the 'Great Divide', ed. N. Spencer. London: Routledge, 43-63.

Whitley, J., 2000. Gender and hierarchy in early Athens: the strange case of the disappearance of the rich female grave. Metis: Revue d'Anthropologie du Monde Grec Ancien XI (1996), 209-32.

Xirotiris, N.I. \& F. Langenscheidt, 1981. The cremations from the Royal Macedonian tombs at Vergina. Archaiologiki Ephemeris 1981, 142-60.

\section{Author biography}

James Whitley's principal research interest lies in Early Iron Age and Archaic Greece, especially Crete, where he has been undertaking fieldwork since 1992 around the ancient city of Praisos. Publications include Style and Society in Dark Age Greece (1991) and The Archaeology of Ancient Greece (2001). From 1 October 2002 he will be Director of the British School at Athens. 